\title{
A corpus-based investigation into the use of metaphor in British business journalism
}

Alan Partington

\section{CpenEdition}

\section{Journals}

\section{Electronic version}

URL: http://journals.openedition.org/asp/3718

DOI: $10.4000 / a s p .3718$

ISSN: 2108-6354

\section{Publisher}

Groupe d'étude et de recherche en anglais de spécialité

\section{Printed version}

Date of publication: 1 December 1995

Number of pages: 25-39

ISSN: 1246-8185

\section{Electronic reference}

Alan Partington, «A corpus-based investigation into the use of metaphor in British business

journalism », ASp [Online], 7-10 | 1995, Online since 25 July 2013, connection on 01 May 2019. URL

http://journals.openedition.org/asp/3718; DOI : 10.4000/asp.3718

This text was automatically generated on 1 May 2019.

Tous droits réservés 


\title{
A corpus-based investigation into the use of metaphor in British business journalism
}

\author{
Alan Partington
}

1 The use of metaphor ${ }^{1}$ in economics writing has received a good deal of attention in the past for example, by recent writers such as Henderson (1982) McCloskey $(1985,1990)$, Klamer (1988) and Mason 1991). However, as Henderson notes, metaphor has often been treated as a way of illustrating points within a general debate about the nature of economics rather than an object of research in itself. The most celebrated example of this is probably to be found in McCloskey's work. This author searches economic texts for the use of metaphors as evidence to prove his thesis that economics writing is rhetoric, giving the lie to the economist's pretence of positivist objectivity.

2 Henderson, Dudley-Evans and Backhouse point out that "McCloskey attributes his insights into the nature of economics discourse to his discovery of literary criticism"(1993: 7) being struck by the parallel between the two genres (I am using this term informally). But this begs the question: if economics writing is the literary criticism of its world, what is the "literature" it criticises? The answer is, at least in part, the practices of business and finance. Economics writing, bound up as it is with grandiose theory, has generally been viewed as a more fitting subject for academic attention than the practical, hard-headed world of business. But just as literature is primary to literary criticism, so financial practice is prior to economic theory and the kind of metaphors employed by those who populate the business world are at least as worthy of study as those of economics.

3 The question remains of what kinds of metaphor are of interest to this study. Not all metaphors have the same "weight". It might intrigue us to know what a pig in a python or movers and shakers refer to. (The first is the bulge in the birth-rate between 1946 and 1964, the baby boom years. Product developers and market people follow the pig as it moves along the python of steady population growth. The second is a term meaning the decision 
makers). However, unless these are part of a set of metaphors all from the same semantic field, if in other words they are simple one-off figures of language, they need not concern us. All sectorial languages are bound to have their own special, as it were, "accidental" metaphors.

The purpose of the present study, on the other hand, is to attempt to uncover what Lakoff and Johnson (1980) call systematic metaphors in the particular sector of business journalism.

Lakoff and Johnson note that many everyday metaphors relating to the same topic can be grouped together into a mega-metaphor on a semantic basis. One of their examples, of relevance to the present study would be the group of metaphors like Is that the foundation for your theory? His argument collapsed. We need to buttress the theory with solid arguments which add up to a mega-metaphor of the form THEORIES ARE BUILDINGS. Similarly metaphors like His ideas have come to fruition, We need to nip that idea in the bud, The seeds of these ideas were planted in her youth are all part of a larger systematic metaphor IDEAS ARE PLANTS. They argue the existence of other systematic metaphors like ARGUMENT IS WAR (Your claims are indefensible, He shot down all my arguments and so on), TIME IS A VALUABLE COMMODITY (Is that worth your while?, I've invested a lot of time in her etc.), COMMUNICATION IS SENDING, LOVE IS A JOURNEY and several more.

The task then was to analyse authentic business journalism and collect metaphors to see whether they could be grouped in similar ways and thus attempt a preliminary taxonomy of the systematic metaphors of this sector.

\section{Theories of metaphor}

However, there is a second more theoretical aspect to the question of metaphor to be considered. Lakoff and Johnson make some very strong claims about the role of metaphor itself in human cognitive processes. They challenge what the see as the prevailing conventional view of metaphor as simply poetic device, as rhetorical icing on the cake of literalness. Metaphor is not just a feature of language, they argue, but the very vehicle of normal thought and action:

we have found ... that metaphor is pervasive in everyday life, not just in language but in thought and action. Our ordinary conceptual system, in terms of what we both think and act, is fundamentally metaphorical in nature. (Lakoff \& Johnson 1980: 3)

Gibbs (1994), primarily a psycholinguist, takes up their mantle and criticises modern pragmatic linguistics, both speech act theory and relevance theory, for misinterpreting and undervaluing the role of metaphor. Speech act theory, argues Gibbs (citing Searle, 1979), explains metaphor in terms of anomaly, of a mismatch between sentence meaning and speaker meaning. If a hearer hears an utterance such as Sally is a block of ice they perceive it as anomalous, as logically defective and flouting the Gricean maxims of quality or relevance (Grice 1975, 1978), and they therefore cast around in their knowledge-of-theworld faculty for an alternative, non-literal interpretation. Gibbs rejects this implication that hearers, in order to fathom metaphorical meaning, must employ cognitive processes which are both different from and in excess of those used to con literal meaning. In his view, there is no priority of one kind of meaning over the other, they are both natural to the process of thought: 
it is misleading to suppose (he writes) that one type of meaning (literal) is

automatically and immediately prior to another (non-literal) (Gibbs, 1994: 228-9)

\section{S} metaphor as flouting relevance, but rather as one way of what is called speaking loosely. Their interpretation of relevance is that an utterance is relevant if it has contextual effect, that is, if it strengthens, contradicts or denies an existing assumption or when it implies something new. An utterance is optimally relevant if it (a) achieves enough effect to be worth the hearer's attention and (b) puts the hearer to no gratuitous effort in winning that attention. In this framework, speaker's are not constrained to saying what they know to be true, and speaking loosely, speaking metaphorically may well be the most effective and economical way of achieving contextual effect, of getting through to the hearer. Nevertheless, according to Gibbs, Sperber and Wilson still imply that hearer's processing of metaphor requires more effort than literal utterance, even though this extra effort may be offset by the extra effect obtained by the force of the metaphor. The metaphor-as-loose-talk view does not assume that metaphor requires special cognitive processes to be understood but it does imply extra processing effort. Gibbs repeats his claim that experimental evidence shows that this is not the case.

11 We thus have three different views of the role of metaphor vis-à-vis the literal: those of the speech act theorists, of Sperber and Wilson, and of Lakoff, Johnson and Gibbs. Each of these approaches is highly theory-driven, none of them use authentic data to support their arguments. In this study, therefore, it was decided to take a large body of texts, analyse the nature of the metaphors they contain to see if an inductive, data-driven study could shed light on this debate.

\section{Data and methodology}

The database for this study consisted of the financial and business sections of The Independent newspaper of 1992 and of The Times of 1993, held on CD-ROM. In addition, circa 800,000 words of running text from The Independent business section were also downloaded onto hard disk so as to be available in a from which could be interrogated by the Oxford MicroConcord concordancer. Although The Economist magazine was not available to me in CD-ROM, paper issues published over the last two years were available for collecting or checking data.

In terms of the methodology involved in analysing the metaphors in business journalism, it was felt not to be sufficient to refer to the business sections of the above newspapers in isolation. If, for example, it was discovered that a systematic metaphor existed of the type BUSINESS IS X (say WAR or GAMBLING), this would be significant only if this metaphor was particularly prevalent in this sectorial language; in other words if it was to be found significantly more frequently in business writing than in the other sections of the paper. If metaphors were also found of the type that POLITICS ARE X, SPORT IS X and ART IS X, this would mean that the metaphor was common to journalism as a whole, perhaps even to the English language. Thus all findings were checked by analysing occurrences of the same metaphor in the other sections of the papers on CD-ROM, and parallel collections of texts each containing roughly 800,000 words were downloaded onto hard disk from the 
Home News, International News, Arts and Sports sections of The Independent to be available to the concordancer.

14 As has been said, it was both necessary and desirable to adopt an inductive approach, to let the data itself suggest what kinds of metaphors might be found in business journalism, rather than guessing a priori what these might be. It was decided that the first step would be to find what the principal vocabulary differences were between business texts and other newspaper texts, since these differences might give some insight into which metaphors were more frequent in this sector. If, to take an example, gamble / gambling was particularly common in business texts in comparison to others it would then be worthwhile to look at related words such betting, casino, chips and so on to try to discover if a mega-metaphor of the type BUSINESS IS GAMBLING existed. For this purpose a program called WordSmith Tools, ${ }^{2}$ written by Mike Scott was used, which first of all prepared a list of the most frequent lexical items in the business texts on hard disk and then another of all the other newspaper section texts treated together. By comparing the two lists, the program provided a third list of all words which were significantly more frequent in business texts, and another of those which occurred significantly less frequently. Both lists proved to be useful. ${ }^{3}$

A final, and this time non-computerised, source of data was a short dictionary of business terms entitled Business Buzzwords and subtitled The tough new jargon of modern business (Johnson 1991). Though semi-humorous in style, it was written by the editor of the highly prestigious journal International Management and offered an interesting reference against which to compare and contrast the newspaper findings.

\section{Results}

From the frequency lists, one group of metaphors in particular stood out, those involving UP and DOWN. This was perhaps not surprising, but what was striking were the variations on the theme. UP and DOWN were expressed in all the following ways (see Table 1).

Table 1

\begin{tabular}{|l|l|}
\hline UP & DOWN \\
\hline ABOVE & BELOW \\
\hline HIGH(LY) & LOW \\
\hline RAISE & FALL \\
\hline RISE & SLIP \\
\hline GROW(TH) & DROP \\
\hline JUMP & SLUMP \\
\hline ESCALATE & SLIDE \\
\hline CLIMB & TUMBLE \\
\hline
\end{tabular}




\begin{tabular}{|l|l|}
\hline SPIRAL & CRASH \\
\hline SOAR & PLUNGE \\
\hline MOUNT & COLLAPSE \\
\hline
\end{tabular}

All these words were relatively much more frequent in the business texts. Closer investigation of the material and of Business Buzzwords also revealed (see Table 2).

Table 2

\begin{tabular}{|l|l|}
\hline UPMARKET & DOWNMARKET \\
\hline UPSTREAM & DOWNSTREAM \\
\hline UP AND RUNNING & DOWNSIZE \\
\hline UP-FRONT & \\
\hline
\end{tabular}

18 Lakoff and Johnson discuss the UP-DOWN metaphors at some length as a central example of what they call orientational metaphors, which have to do with spatial orientation. Other such metaphors would include IN-OUT, FRONT-BACK, etc., and for Lakoff and Johnson, they are important because they "arise from the fact that we have bodies of the sort we have and that function as they do in our physical environment". They are the leading proof for Lakoff and Johnson, that metaphors are the result of experience and are therefore basic, natural features of thought and action. They point out that the UP-DOWN metaphor has a number of extensions, two of which are relevant to the field of business, namely the metaphors UP IS MORE, DOWN IS LESS and UP IS BETTER, DOWN IS WORSE. There is probably no sectorial language in which the metaphors UP-DOWN are more apparent than in business. Concentrating on the UP part of the metaphor, there is certainly no lack of evidence to show that UP IS MORE:

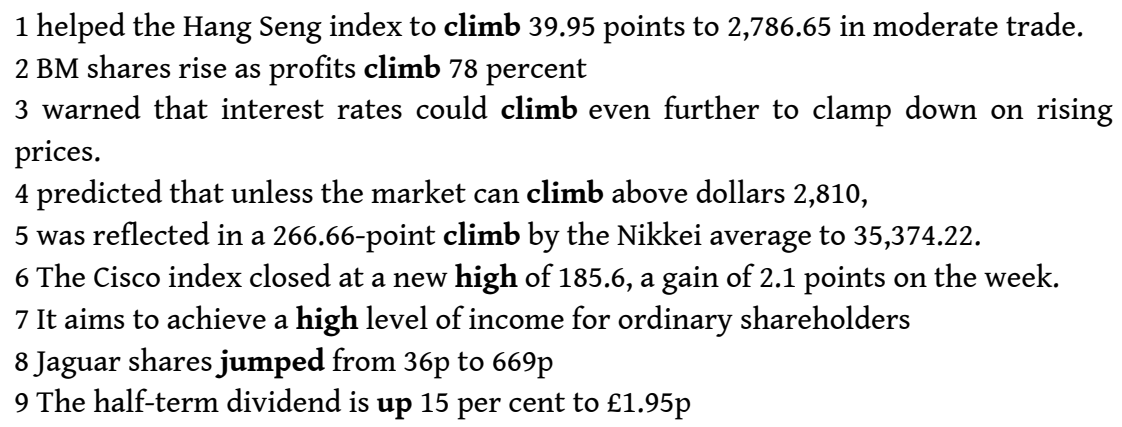

However, it is by no means the case that UP is always, or even predominantly BETTER. When, for example, costs, debts, inflation or unemployment are up, then this is far from good. In fact there are even items, notably mount, escalate and spiral which are all used specifically to express that UP is definitely WORSE (the following concordances are all derived from The Independent material):

Concordance of mount:

$1 \mathrm{Mr}$ Lapointe and his secretariat are facing a mounting barrage of accusations, 
2 in a Europe without blocs. If tensions mount between and within the former Sovie 3 Group of Seven countries. It follows mounting concern in the West over the build 4 tional Trade in Endangered Species, amid mounting controversy over the conduct

5 defend himself after growing alarmed at the mounting cost of his legal bills. $\mathrm{Mr}$ 6 James Rodwell, 32, a company director facing mounting debts who tried to extort 7 the company's property operations, and to overcome mounting debts.

8 in 1942, at a time when RAF aircraft losses were mounting disastrously. Harris 9 action would expose them to the prospect of mounting fines and eventual seizure 10 man, declined to comment on the effect BR's mounting losses might have on the 11 City Page $33</$ st $><\mathrm{dt}>891019</ \mathrm{dt}><\mathrm{hl}>$ Mounting losses at Dan-Air $</$ hl $>$ 12 plunged on the foreign exchanges with concern mounting over the continued $a b$ 13 ima borrowers defaulting on their loans and losses mounting, Pima went bust. 14 index shedding 8.6 points to 1,574. PARIS: Mounting political uncertainty sent 15 ings in some districts, comes amid signs of mounting pressure on NHS budgets in

16 else to initiate a world economic upswing. But mounting protectionist pressures 17 But it became clear that Mr Morley was under mounting strain. The delays grew 18 dress the Security Council today as concerns mount that the lives of peacekeepers

19 Education Reporter $</$ bl $><s t><p>$ FEARS are mounting that increasingly soph 20 whose members have been responsible for a mounting tide of violence including

\section{Concordance of escalate:}

1 to cut interest rates, but by escalating a guerrilla war on the lira to a frontal assau

2 The company also had to contend with the escalating cost of both public and

$3<\mathrm{p}>$ The escalating costs of the Magnox stations, which were abruptl

4 hopes of raising up to $£ 1.6 \mathrm{bn}$ to meet the escalating costs of the Channel tunnel

5 the Magnoxes were withdrawn that the escalating costs of reprocessing and

6 The slowdown in military spending and escalating costs of armament programme

7 Despite the jitters the cost escalation has caused in the City, the French appear to 8 used of having mistakenly relied on the continued escalation of house prices. Bob 9 BA alliance row to escalate. The row over British Airways' proposed dollars 75

10 ing immediate repayment that would have escalated the country's financial crisis.

11 the present value of the pound look like escalating the slowdown in the economy.

12 but in an era of commercial escalation the Olympics these days are not so much 13 invariably developed into screaming matches escalating to food-fights, then Malk

14 sharp falls in prices combined with escalating unemployment and repossessions 15 national Economic Outlook today that an escalating world trade war, instability

Concordance of spiral:

1 inties that have become a dreadful spiral. All have tried to link their currencies to 2 spending to avoid succumbing to the spiralling costs of unification. Jurgen

3 took fright at indications that the spiralling costs of the Channel tunnel would not

4 sharply following revelations of spiralling costs. Admission of a £2bn cost overrun

5 recent growth on a diet of debt. Spiralling interest rates have tightened the noose

6 With public sector borrowing spiralling, Norman Lamont did not in truth have 

be SOFT IS WEAK as in soft currency, or SOFT IS EASY as in soft option or SOFT IS LESS as in soft prices. Sometimes HARD IS TANGIBLE as in hard transactions, at others HARD IS INFLEXIBLE - hard bargain. But on other occasions the metaphorical vehicle of these items appears to be rather indeterminate (as in soft commission), which lends weight to the Lakoff, Johnson and Gibbs claim that metaphor is not secondary to the literal. If it is not possible to translate a metaphor into a literal alternative then the metaphorical meaning must be primary, must be semantically primitive.

It can be seen how these items are reserved for the rise of something bad, they in fact have negative connotations or what Louw (1993) would call a negative prosody.

Another relatively frequent orientational metaphor in business is AHEAD-BEHIND, although the AHEAD part of the metaphor is much more developed than the BEHIND. Share prices, stocks and so on can edge ahead, move ahead, race ahead, forge ahead, surge ahead and sprint ahead. This metaphorical use appears to be part of a systematic metaphor of the type THE STOCK MARKET IS A RACE. More will be said of sports metaphors later. A word must be spent on the particular temporal metaphorical use of AHEAD. In phrases like:

- Looking ahead to economic and political union...

- ...difficult trading conditions ahead..

clearly we have a metaphor AHEAD IS THE FUTURE. But in the expression ahead of which is extremely common in business journalism:

- Conditions ahead of the 1992 budget..

- SG Warburg made positive noises ahead of today's shareholders' meeting...

AHEAD IS THE PAST. This, one suspects, could cause problems for a non-native student of business English.

Another common experiential metaphor in the business texts is based on the HARD-SOFT opposition. Taking soft first, we find soft prices, soft rates, soft credits and soft commissions. Hard is to be found in hard cash, hard transaction and hard bargain. A number of items can be either hard or soft - option, sell, landing and currency (see Table 3).

Table 3

\begin{tabular}{|l|l|l|}
\hline SOFT & HARD & SOFT \& HARD \\
\hline prices & cash & option \\
\hline commissions & bargain & sell \\
\hline credits & transactions & landing \\
\hline rates & & currency \\
\hline
\end{tabular}

Business people themselves are notoriously hard-boiled, hard-nosed, hard-headed or hardline. When they wish to be especially tough they also play hard-ball, which is rather more gruelling and aggressive than soft-ball. This is another sporting metaphor, this time from baseball. When their companies are hard-hit, executives are hard-pressed. 
Returning to the relative frequency lists, an examination of those items which are relatively uncommon in business journalism reveals a large number of the personal pronouns of English, along with titles like $\mathrm{Mr}$ and Mrs and verbs requiring personal subjects like know, try and say. This provides evidence that business texts are relatively impersonal, tending to deal with impersonal trends rather than people's actions as many other parts of the newspaper do. Among the relatively infrequent items there are also a number of past tenses of common verbs such as was and did. This is probably because business is very much interested in future events. Investigating this hypothesis further, the following vocabulary was found to be extremely frequent in the business texts relative to the other newspaper sublanguages (see Table 4).

Table 4

\begin{tabular}{|l|l|l|}
\hline believes & forecast & fear(s) \\
\hline confidence & outlook & doubt(s) \\
\hline expectations & speculation & apprehension(s) \\
\hline estimates & likely & \\
\hline
\end{tabular}

From this evidence we might hazard the existence of a systematic metaphor of the sort BUSINESS IS FORECASTING or GUESSING, and often enough, BUSINESS IS FEAR.

Other items of below average frequency are war, army and military. Further investigation revealed that, in the CD-ROM and hard-disk material, items such as war, warfare, battle were less frequent than in other sections. This was very much in contrast to the author's original intuition about business writings, and also to many of the entries in Buzzwords (we might recall the subtitle - the tough new jargon of modern business). Buzzwords gives all sorts of military or violence metaphors:

Table 5

\begin{tabular}{|l|l|l|}
\hline war cabinet & frag & take no prisoners \\
\hline war chest & hired guns & dawn raid \\
\hline war room & hit squad & hip-shooter \\
\hline bodycount & kill a deal (i.e., conclude) & \\
\hline saboteur & killer bee & \\
\hline
\end{tabular}

31 However, in all the authentic material held on CD-ROM, only one of these - war chest (meaning a special fund set up by a company to fight off a take-over bid) was found. There might be two explanations for this disparity. Firstly, Johnson's book, compiled over the eighties may reflect the more confident and aggressive ethos of business in that period. Secondly, there is always a difference between the language used by the participants of any given professional sector, and the language used about the sector - all 
studies of sectorial language should keep this distinction in mind. Businessmen may well talk differently than business commentators and we have already noted the tendency of business journalism to be formal and impersonal. Having said this, however, it is probably the case that the conflictual nature of business is probably exaggerated by its practitioners. It is more glamorous to see oneself as a warrior than a salesman, which, when all is said and done, is the principal activity of the businessman. It is interesting to note that agreement, alliances, harmonise, harmonisation, co-operate, co-operation and even helpful are all relatively frequent in business journalism compared with the other newspaper sections.

Business people, incidentally, have quite a range of complimentary ways of talking about themselves. A decent financier is a wizard (especially if Welsh), anyone who writes a book on business is a guru. A good manager has the V-word (vision) and champions their company.

So BUSINESS may - or may not - be WAR. It is most definitely, as has been said, SPORT, and especially A RACE. A company which is world class will have an excellent track record and will be found in the fast lane or track (note the metaphor FAST IS GOOD). The word front-runner is more common on the business pages than the sports. Your turf is your own territory, your area of business. Companies emerge as favourite to accomplish some plan:

- Allied Lyons is tipped as favourite to buy the brands...

- BSN, the sprawling French group, has emerged as the new favourite for the

Scottish stake... (i.e. to buy out the Scottish and Newcastle Breweries Co.)

If BUSINESS is essentially a HORSE RACE, then there is no surprise in the amount of betting which goes on:

- there is something about penny shares that appeals to tipsters.

- they say Chrysler has essentially 'bet the company' on a series of new models..

- those who recently bet against sterling...

- they are more at home having a flutter than making hard nosed investments

- Gambler Bock raises the stakes at Lonrho

Other prominent systematic metaphors include BUSINESS TAKE-OVERS as HUNTING with predators, sharks, shark repellents, stalking horses and vulture capitalists all at work. BUSINESS INSTITUTIONS are seen as BUILDINGS with Chinese walls, gatekeepers, and glass ceilings. Occasionally the boss carries out some housecleaning. Companies can be seen as many entities. We have the A COMPANY IS A PERSON with or without deep pockets or teething troubles, A COMPANY IS A MACHINE with managers working levers, and which might need a jump-start or kick-start. A COMPANY IS also AN ANIMAL which may have a spider organisation or may be a dinosaur. Or more probably it is A PLANT which the managers grow until it becomes mature, avoiding if possible mushroom management and starting out with plenty of seed corn. ${ }^{4}$

\section{Conclusion: the living and the dead}

As regards the theory of metaphor, has any information been unearthed to resolve the controversy between the pragmatists' and the Lakoff, Johnson and Gibbs view of metaphor? We can probably conclude that they are in fact both right within the framework of their own arguments, but they are dealing with different sorts of metaphor. There is a cline in the originality of metaphorical use, from the unusual, through the welltrodden, to what is usually called the dead metaphor. The Lakoffian approach, concerned 
as it is to demonstrate the all-pervasive nature of metaphor in language and thought, tends to concentrate exclusively on the well-trodden to dead end of the scale ARGUMENT IS WAR, IDEAS ARE OBJECTS, THE MIND IS A MACHINE and so on. If we recall Gibbs' argument that hearers take no longer to process a metaphor than any eventual literal equivalent, this would seem predictable if the metaphor in question is one they are already familiar with.

But this study has been concerned with the language of a sector to which the author and most of the readers will be outsiders and in which many of the metaphors are not only unusual but also opaque until explained. At times processing difficulties will almost certainly have been experienced. The Lakoff-Johnson-Gibbs school was principally making claims about English in general. Perhaps more attention to sectorial languages would have made them more sensitive to the pragmatists' ideas about processing difficulties and strategies.

A final thought which arises from this study concerns the nature of well-trodden and dead metaphors. It should be remembered that what is a dead metaphor and invisibly transparent to people working in a sector may be quite opaque to outsiders. How does someone who is not a member of a particular discourse community ${ }^{5}$ know if a given metaphor is alive or dead for that community? The answer to this question is to observe the co-text and the clues to be found in the way the metaphor collocates. Henderson notes the frequency of what are usually called "mixed metaphors" in economics texts, and I found several examples in business (both from The Economist, August 26th 1995):

- And newly liberated South African companies are already compiling shopping lists

of potential targets abroad.

- inflation...has fallen recently primarily because of falling food prices. It could easily pick up again.

(An object falls downwards, but pick up refers to speed in a forward direction)

In these examples neither targets, nor falling nor speed picking up are being used with any metaphorical weight at all. These are not really mixed metaphors, only technical jargon.

Another clue to a dead metaphor is in the conventionality of its collocations. A good example is the HEALTH metaphor. Businesses or currencies are often described as healthy, robust or strong, but never as fit or sturdy. Conversely, they are described as weak or ailing, but never as ill or frail or sick or feeble. Only a part of the possible vocabulary set of the vehicle of the metaphor is used to describe the topic. This means that expressions like $a$ strong mark, an ailing business have ceased to be parts of a metaphor and have become fossilised collocations. New expressions based on the original metaphor - the pound is ill today - would probably be heard as jokes.

One can also look at noun-verb or noun-adjective collocation in the phrase to see if evidence of metaphorical intent is present. To illustrate this, we might look at the use of the business term flow. A good example of flow retaining a metaphorical force was found in the international news section of The Independent:

His purge has been West Germany's much-needed transfusion, as its 26,500 new citizens bring with them precious skills. Although East Germany managed to staunch the flow on the eve of its 40th birthday, observers said it was still in danger of bleeding slowly to death (my emphasis)

By contrast the business texts contain no such extended metaphors concerning flow. The concept of MONEY AS A LIQUID whose movement therefore flows is a completely dead metaphor as can be seen from the way flow and especially cash-flow collocates. It is 
generated or helped, it can be positive or negative, one can run into cash flow difficulties. It can even be under pressure, which, if it were a liquid would result in greater speed of flow, the opposite of what the writer intended.

The point is, of course, that these metaphors have become technical words. They have no figurative content, and to all intents and purposes are no longer metaphors at all. We might even posit a general rule of metaphor, which states that a metaphor ceases to be a metaphor when it has no simple literal alternative, or when a metaphor is much more common than its literal alternative in its genre. ${ }^{6}$ This conclusion gives strong support to Gibbs' contention of the hazy boundary between the literal and the non-literal. However, the evidence of this study suggests that the principal Lakoffian claim - that not only language but also thought is fundamentally metaphorical in nature - remains unproved. Language, as we have seen is heavily metaphorical, but the abundance of dead and dying metaphor - that is, metaphor which has become literal - could well mean that the cognitive processes behind the linguistic expression are less metaphorical than they might at first appear.

\section{BIBLIOGRAPHY}

Bollettieri-Bosinelli, R.-M. 1988. Quando parlano le metafore. Bologna: CLUEB.

Gibbs, R. 1994. The Poetics of Mind, New York: Cambridge University Press.

Grice, H. 1975. « Logic and Conversation ». In Cole, P. and J. Morgan (eds), Syntax and Semantics 3: Speech Acts. New York: Academic Press.

Grice, H. 1978. "Further notes on logic and conversation". In Cole, P. (ed.), Syntax and Semantics 9: Pragmatics. New York: Academic Press.

Henderson, W. 1986 [1982]. "Metaphor in economics". Economics 18/4, 1147-157, (Reprinted in Coulthard, M. (ed.), Talking about Text. Discourse Monograph no.13, University of Birmingham: English Language Research.

Henderson, W., T. Dudley-Evans and R. Backhouse. 1993. Economics and Language. London: Routledge.

Johnson, M.1991. Business Buzzwords, The Tough New Jargon of Modern Business. Oxford: Blackwell.

Klamer, A. 1988. “As if economists and their subjects were rational”. In Nelson, J., A. Megill and D. McCloskey (eds.), The Rhetoric of Human Sciences. Madison, WI: University of Wisconsin Press.

Lakoff, G. and J. Johnson. 1980. Metaphors We Live By, Chicago: University of Chicago.

Louw, B. 1993. "Irony in the text or insincerity in the writer? The diagnostic potential of semantic prosodies”. In Baker, M., G. Francis and E. Tognini-Bonelli (eds.), Text and Technology. Amsterdam: Benjamins.

McCloskey, D. 1985. The Rhetoric of Economics. Madison, WI: University of Wisconsin Press.

McCloskey, D. 1990. If You're So Smart: the Narrative of Economic Expertise. Chicago: University of Chicago Press. 
Malmkjaer, K. (ed.). 1991. The Linguistics Encyclopedia. London: Routledge.

Mason, M. 1991. "How language makes economics possible". Paper presented at the Rhetoric and Economics Seminar, Birmingham (UK).

Scott, M. 1996. WordSmith Tools. Oxford: Oxford University Press.

Scott, M. and T. Johns. 1993. Microconcord. Oxford: Oxford University Press.

Searle, J. 1979. “Metaphor”. In Ortony, A. (ed.), Metaphor and Thought. Cambridge: Cambridge University Press, 92-123.

Sperber, D. and D. Wilson. 1985-86. "Loose talk". In Proceedings of the Aristotelian Society. Oxford: Blackwell, 153-172.

Sperber, D. and D. Wilson. 1986. Relevance: Communication and Cognition. Oxford: Blackwell.

Swales, J. 1990. Genre Analysis. Cambridge: Cambridge University Press.

\section{NOTES}

1. For a definition of metaphor see Bollettieri-Bosinelli, 1988 (Introduction) and Malmkjaer, K. (ed.) 1991: 308-312.

2. At the time of writing only in prototype version.

3. A methodology including the use of the program WordSmith Tools for studying some of the particular features of a genre is of general application. Here attention is concentrated on metaphor in business journalism, but the same approach can obviously be used in the study of any other genre or sectorial language, and could be employed for many other kinds of lexical or phraseological research (e.g. into idiom, phraseology and even particular grammatical features of a genre (in this study, favoured tense usage, lack of personal pronoun use etc).

4. Henderson (1982) notes the presence of very similar metaphors in economics, in which the ECONOMY IS A PERSON (usually ailing), or A MACHINE (which can overheat) or A PLANT (hopefully growing or blossoming).

5. See Swales (1990 23-9) for the definition of "discourse community".

6. The transformation of metaphor into a literal descriptive item is, of course, a common diachronic process. Few speakers think about the original meaning of, say, stereotype (a template once used in printing) or sniper (one who shoots snipe, a game-bird), but their modern meanings result from the demetaphorisation of an original metaphor.

\section{ABSTRACTS}

In this paper, the author presents a (principally) corpus-based analysis of the nature of the systematic metaphors employed in business journalism. In the light of the results of this analysis, a comparison of two influential modern theories of metaphor - the pragmatic and the cognitivist - is attempted. The suggestion is made that the methodology used in the analysis is productive, i.e., can be used to study many of the lexical aspects of genre. 
L'article présente une analyse de la nature des métaphores récurrentes dans le discours journalistique des affaires. L'analyse est conduite principalement à partir d'un corpus de textes. À la lumière des résultats observés, on tente une comparaison entre deux importantes théories modernes de la métaphore : pragmatique et cognitive. La méthode utilisée pour cette analyse paraît productive, ou pourra l'étendre à l'étude de nombreux aspects lexicaux de genres particuliers.

INDEX

Mots-clés: collocation, entreprise, journalisme, métaphore, genre, WordSmith

Keywords: business, journalism, metaphor

\section{AUTHOR}

\section{ALAN PARTINGTON}

Alan Partington teaches at the University of Siena. 